This is the accepted manuscript of the article, which has been published in International Journal of

Public Sector Management , 2020, 33(4), 401-418.

\title{
Budgetary bias in the Finnish public hospital system
}

\section{Alpo Karila}

Researcher, Development and Innovation Centre, Tampere University Hospital

Jarmo Vakkuri

Faculty of Management and Business, Tampere University, Tampere, Finland

\section{Juhani Lehto}

Faculty of Social Sciences, Tampere University, Tampere, Finland

\section{Corresponding author}

Alpo Karila

Researcher, Development and Innovation Centre, Tampere University Hospital

Tel. +358 50528 2317, e-mail alpo.karila@gmail.com

\section{Acknowledgements}

This study was financially partly supported by the Competitive State Research Financing of the Expert Responsibility area of Tampere University Hospital.

\begin{abstract}
Purpose

The purpose of the study was to analyze the dynamics of budgetary biasing in the context of public hospitals.
\end{abstract}

\section{Design}

The study applies theories of accounting and budgeting behaviors in the specific institutional context of health care systems. Based on the theoretical framework, data from interviews with hospital budget officers were analyzed using qualitative content analysis.

\section{Findings}

A typology of biases is provided. It proved to be useful and highlighted the central empirical assumptions and preliminary results of biasing dynamics.

\section{Practical implications}

Understanding the logic of budgeting actors and the drivers of bias may help explain why bias so often appears in health care budgeting. It further contributes to understanding whether the bias is functional or dysfunctional. 


\section{Originality / Value}

The concepts of budgetary bias are rarely used in the context of health care budgeting, so the study fills a gap in research knowledge.

\section{Keywords}

budgetary bias, typology of biases, budget actors and budget community, public hospital system

\section{Introduction}

Budgeting is the central administrative and management process for the allocation of resources at all levels of government. It has multiple meanings: to predict, plan and control the future, to be the baseline for performance evaluations and external accountability, and to serve as a tool to motivate budget-holders. The aim of budgeting is to ensure the best use of the available resources through negotiations using the power of the decision-makers (Anessi-Pessina et al., 2016; Huang and Chen 2010; Schick 2009; Wildavsky 1975 , 1988). However, although budgeting is an important managerial tool, the budgeting process itself is not completely rational, because budget-makers have inconsistent and conflicting aims, and they are boundedly rational human beings who are inclined to gaming and bias in their actions and predictions (Thaler, 2015; Huang and Chen, 2010; Van der Stede, 2000; Simon, 1991; Collins et al., 1987; Wildavsky, 1975, 1988). Budgeting involves "ritualistic practices and actual behaviours" (Anessi-Pessina et al., 2016), and the link between budget decisions and actions may be "a very loose one" (Brunsson, 1989).

There are many reasons why the health care context is subject to budgeting problems. Cost containment, access to care, and quality assurance is a tricky combination in a world of unlimited service needs and limited resources (Kissic, 1994; Johanson and Vakkuri, 2018; Berwick et al., 2008). Spending constraints in health care have the potential to directly affect all voters, making health care a politically sensitive issue (White, 2013). There are numerous principal-agent relationships and financial flows between actors, as well as information asymmetries and problems in monitoring medical actions and their outcomes (Ouchi, 1979; Smith et al., 1997; Eijkenaar, 2013).

Furthermore, the product of health services is intangible: its production and consumption occur simultaneously in face-to-face interaction between patients and professionals (Pettersen, 1995). While the content of health care is heavily regulated by legislation, health care organizations act together like a clan, emphasizing institutionalized traditions and professional autonomy. The behavioral and output control of action is managed through professional judgment and accepted medical practices (Ouchi, 1979; Pettersen, 1995). Over the last three decades, hospital governance models have changed (Saltman et al., 2011) towards more competition between hospitals, more patient choice, and more public-private collaboration (Scott et al., 2000; Kurunmäki, 2004), opening new, partly unintended fields of gaming and biasing behaviors (Propper and Leggie, 2011).

The key concept in the article is budgetary bias. The origins of budgetary bias grew out of the concept of organizational slack in the behavioral theory of the firm (Cyert and March, 1963). Following Lukka (1988), intentional budgetary bias is "a deliberately created difference between the budgeting actor's forecast about the future, and his or her submitted budget proposal." Biasing is a tool affecting the standards against which performance is assessed and, from another perspective, a means of obtaining unnecessary extra resources. Furthermore, personal goals may introduce biasing behavior. Biasing behavior is possible in all functions and at all levels of an organization. 
Budgetary bias has two subcomponents: budgetary slack and upward bias. Budgetary slack occurs when the budget proposal is intentionally made easier to achieve than the honest forecast, "underestimating revenues and productive capabilities and/or overestimating costs and resources required to complete a budgeted task" (Dunk and Nouri, 1998). An upward bias means biasing in the opposite direction, a deliberate overstatement of budgetary targets. The overstatement of budgetary targets may sometimes be a counterbiasing in order to eliminate the probable budgetary slack of other actors (Lukka, 1988).

The concepts of biasing are not widely applied in the context of health care research. This became evident when we conducted searches of the Business Source Elite, Scopus, and Medline databases in February 2017. The time horizon of the database searches was 1990-2016, and the searches targeted the titles, abstracts, and keywords of peer-reviewed articles. Budgetary bias and budgetary slack were found as concepts in 12 articles, which is a small number considering the 6,000-8,000 articles related to health care budgeting found in each database. Furthermore, budgetary bias and budgetary slack were not key concepts in any of the articles. Thus, the study aims to fill this gap by extending knowledge about budgeting in public sector health care organizations, especially in the context of public hospitals.

Budgeting and budgetary biasing are multifaceted fields to investigate (Anessi-Pessina et al., 2016). We apply theories on accounting and budgeting behaviors in the specific context of the institutional characteristics of health care systems. The purpose of the study is to introduce the concepts and forms of budgetary bias, analyze the mechanisms through which budgetary bias is created, and consider the impact of biases on the budgeting process. The budgetary bias concepts and theories are illustrated and tested in an analysis of budgeting processes in Finnish public hospital organizations.

The next section of the paper introduces the relevant conceptualizations for our analytical framework. The empirical context, including a short overview of the health care system in Finland, and the data and methods are introduced in the third section. The fourth section reports the empirical analysis based on interviews with chief financial officers (CFOs) of hospital districts. The final section presents the results, discussion, and conclusion.

\section{Conceptualizing budgetary bias in health care}

Budgeting has no single dominant paradigm. The history of public budgeting theories, however, can be explored as a contest between rationalism and incrementalism (Swain and Hartley, 2001). The theory of economic rationalism assumes that budget-makers are "Econs" (Thaler, 2015) that can balance different preferences and time spans and produce and utilize the perfect information needed, even in situations that change rapidly and unexpectedly (Schick, 1988). The rationality of incrementalism is adaptive and based on the idea of budgeting as a historical continuum, where the institutionalized norms, rules, and routines restrict rapid and significant changes in resource allocation (Wildavsky, 1975, 1988; Schick, 2009). Budget participants have conflicting interests, and budgetary decision-making is always a time-bound compromise between budget-makers. Gaming and biases are inevitable aspects of this interplay.

Rational and incremental elements are constantly and simultaneously present in budgeting practices. The rational elements in budgeting have been observed to gain strength during fiscal stress (Schick, 1986), and even the manipulation of revenue estimates increases, mainly for political reasons (Anessi-Pessina and Sicilia, 2015). The incremental features of budgeting-or decremental features in times of austerity-do not disappear, because they are so deeply rooted in the structures and norms of budgeting processes (Budding and Rossi, 2015; Hyvönen and Järvinen, 2006; Swain and Hartley, 2001; Wildavsky, 1988). 
The key participants in the budgeting process are the budget-makers-i.e., budgeting professionals-and the political decision-makers. Budget participants form a budget community that shares common attributes worldwide, despite the differences in health care systems (White, 2013). Budget-makers are divided into two groups with different orientations toward the budgeting process. They are either advocates in the controlled units that watch over details or else guardians in the controlling units that emphasize totals. Guardians and advocates have conflicting aims, but in an iterative negotiation game, they must also learn to cooperate and trust each other. Realistic, feasible budgets depend on trust and calculability, which in turn are interrelated. In the context of public hospitals, the authority of health care professionals over the budget formulation and especially budget execution is great, both because of their professional authority and because the expenses are realized in their daily treatment choices. The two budgeting professional groups-advocates and guardians-are expected to maximize the level of population health (White, 2013).

Political decision-makers are the guardians at the highest level of the budgeting process. As far as health care professionals follow the logic of appropriateness-what is necessary for patients - politicians' references vary more between economic constraints and service pressures (March and Olsen, 2013). Political decision-makers face both the public demand for health services and, especially in times of economic stagnation, the need to avoid budget deficits. In those times, politicians seek to avoid criticism and minimize blame by avoiding service cuts, by avoiding budget deficits, or by balancing between the two (White, 2013; Hood, 2007).

In the budgeting literature, conflicts and manipulation in the budgeting process are often analyzed through the concept of gaming and maneuvers, which allows for several interpretations (Hofstede 1968; Wildavsky 1975, 1988; Collins et al., 1987; Pettersen, 1995; Huang and Chen, 2010; White, 2013). In the management accounting literature, the somewhat strict concepts of budgetary bias and budgetary slack have often been used in the analysis of budgeting problems (Otley, 1985; Lukka, 1988; Dunk and Nouri, 1998; Van der Stede, 2000; Davila and Wouters, 2005; Anessi-Pessina and Sicilia, 2015).

Budgetary bias is the intentional, deliberately created difference between the budget proposals and the best possible forecast about the future. The intentions of biasing are to obtain extra resources or to make the targets of performance evaluation easier to achieve, or in some cases to provide the higher level management with an opportunity to motivate their subordinates with the resources made available through moderate slack (Lukka, 1988).

Moreover, it is evident that unintentional estimation errors and honest budget forecasts (Otley, 1985; Lukka, 1988) include biasing elements that stem from the budget participant's bounded rationality (Simon, 1991) and from cognitive constraints and cognitive bias at the level of individual actors (Kahneman, 2002). Health care is known for its commitment to evidence-based operational principles, even if there are "neither good output measures nor good causal knowledge" (Pettersen, 1995). For instance, the prognoses concerning the need for care and its costs are based on data that is always defective, emphasizing the uncertainties of understanding the future. The processing rules of defective information and estimating rules concerning the uncertain future can be understood on the basis of prospect theory, emphasizing loss aversion and, for this reason, probably including unintentional bias (Kahneman, 2002; Rozin and Royzman, 2001). The omission of information may be dangerous. Ignoring uncertainty in this context can decisively affect the final results of the prognoses (Griffin et al., 2011).

Budgetary bias is a subjective phenomenon (Lukka 1988), and as such, it is difficult to operationalize and measure directly. Intentional bias, unintentional bias, and blame avoidance are three separate phenomena. They merge in the budgetary process in a special way. Each contributes to its own kind of bias. This is why it is difficult or even impossible to separate different impacts from each other in the budget figures. 
The typical budgeting process includes three separate, iterative and partly simultaneous phases: preparation, negotiations and final decision-making. With regard to hospitals, we suppose that the risk of unintentional cognitive biases is the most obvious in the preparatory phase when making forecasts and engaging in negotiations inside the same organization. Intentional gaming and biases appear mostly in negotiations between separate organizations if they have the stance of principal/guardian or agent/advocate. Blame avoidance-e.g., by postponing unpopular but necessary decisions-is related to political decision-making, even if it happens at all levels of organizational decision-making.

\section{Empirical context, data, and methods}

\section{Finnish health care system and public hospital organizations}

The Finnish health care system, as in the other Nordic countries, is a Beveridge-style system: health care is mainly funded by general taxation and operated by public institutions. The main sources of funding are local government taxation (36\%), central government taxation (24\%), obligatory sickness insurance payments (15\%), and patient co-payments (19\%) (Seppälä and Pekurinen, 2014). The health care system in Finland has long been decentralized to local governments. The important actors in Finnish primary health care are the municipalities (311 in 2017) and their joint authorities. On the other hand, the main operators in specialized medical care are hospital districts (20 in 2016), which are also owned by the municipalities. Altogether, the number of purchasers is 151 (THL, 2016).

An important change in the control of health care finances happened in 1993, when the central government subsidies previously paid directly to the hospitals were redirected to municipalities in order to support their role as principals governing the public funding of hospitals. This reform created (without specific administrative legislation) an unofficial and internal principal-agent structure with purchaserprovider models split between the municipalities and hospital districts (Tynkkynen et al., 2013). The reform created new types of problems for municipalities in controlling hospital districts, including the acquisition of services and budget allocations (Hyvönen and Järvinen, 2006).

The statistical data (Appendix 1) indicate, firstly, that there are many principals (4-29 municipalities) to control one agent (the hospital district). Changes in the catchment populations of hospital districts have been remarkable. Furthermore, many small and medium-sized hospital districts have also been given the task of operating all or part of their municipality's primary health and social care. Secondly, data indicate that the average budget expenditure overrun-i.e., compared to the original budget-during the 20102014 period in all hospital districts was 3.2 percent. The average was greater than four percent in seven hospital districts. In five hospital districts, substantial supplementary budgets were used every year. Furthermore, some hospital districts had large deficits on their balance sheets. There are several important reasons for studying the potential budgetary bias behind the observed accuracy of budget figures.

\section{Budget-makers in Finnish public hospitals}

The main advocate budget-makers in the hospitals are the leaders of operational units (clinics, departments, divisions) and professional groups, and the representatives of the professional groups' trade unions. Their preferences lie in the details. Respectively, the guardians inside the hospital district are members of the management team: the hospital district director and associated staff, including directors of medical and nursing services, the finance director, and the director of human resources. Their preferences lie in the totals, and they often tend to manage the hospital budget in a prudent way (White, 2013). 
However, the role of the guardians inside the hospital district is more ambiguous than that of the advocates. Hospitals are professional organizations, and the medical and nursing directors may regard their role to involve both the leadership and trusteeship of their professional groups. In this kind of environment, communication and cooperation between the hospital district director and the board is intense, and one of the hospital director's most important roles is to negotiate and mediate between the operative organization and political decision-making (Rogers, 2012).

Furthermore, negotiations and contracts between hospital districts and municipalities-either explicit or implicit-over the acquisition of services are an essential part of the annual local government budgeting process in Finland. Municipal managers and the leaders of municipal primary health centers hold central positions as the "outside guardians". When unanimous, their authority over the annual budget frame of hospital districts is significant, as is their de facto veto position on decisions concerning investments and changes in service structures (Karila et al., 2015).

Table 1 . The actors of the budget community in the Finnish public hospital system.

\begin{tabular}{|l|l|}
\hline Advocates & $\begin{array}{l}\text { Leaders of clinics and other } \\
\text { operational units }\end{array}$ \\
\hline $\begin{array}{l}\text { Guardians inside } \\
\text { hospital district }\end{array}$ & $\begin{array}{l}\text { Management team and other } \\
\text { budgeting experts in the central } \\
\text { administration }\end{array}$ \\
\hline $\begin{array}{l}\text { Guardians within } \\
\text { municipalities }\end{array}$ & $\begin{array}{l}\text { Representatives of municipal } \\
\text { managers and municipal health } \\
\text { center managers }\end{array}$ \\
\hline $\begin{array}{l}\text { Final decision- } \\
\text { makers }\end{array}$ & $\begin{array}{l}\text { Board (and council) of hospital } \\
\text { district, which are nominated by the } \\
\text { municipalities of the district }\end{array}$ \\
\hline
\end{tabular}

\section{Data and methods}

The empirical analysis reflects the theories of budgetary bias in the context of Finnish public hospital organizations (i.e., hospital districts). We use several sources of empirical data for this purpose. The main sources of data are 12 face-to-face interviews and eight telephone interviews with the chief financial officers (CFOs) of all 20 Finnish hospital districts. Documentary data, including financial statements and other documentation provided by the hospital districts for the 2010-2014 period, were used as complementary information alongside national-level statistical and benchmarking data (THL, 2018).

CFOs are responsible for the budgeting process and the financing of their organizations. Thirteen of them had earlier worked in leading positions in finance or management administration in the municipal sector. Five CFOs had additional experience from positions in the private sector. The interviewer also has significant experience of working as a CFO in a town and a hospital district.

The interview data were collected in the winter of 2015. The interviews were semi-structured, focusing on hospital district budgeting and economic governance in general and the relationship between the hospital districts and the municipalities in particular. In the interviews, CFOs analyzed and interpreted their own actions as guardians. In addition, they made observations about the actions of clinic managers, municipal managers and the hospital district board. As a single group, CFOs are highly important informants to provide comparable and valid information on hospital budgeting in Finland. 
The interview data were analyzed using theory-driven qualitative content analysis (Alestalo and Åkerman, 2010, Silverman, 2006). To determine the biasing dynamics, the analysis focused on three central stages of the budgeting process in which the actors' points of view are clearly differentiated. The analysis includes direct quotations (in italics) from the interviews with the CFOs.

Table 2. The scheme of the empirical analysis.

\begin{tabular}{|l|l|}
\hline $\begin{array}{l}\text { Unintentional cognitive biases and intentional } \\
\text { biases in the preparatory phases of budgeting }\end{array}$ & $\begin{array}{l}\text { The interaction of CFOs and "clinic managers" in } \\
\text { general and particularly during the preparation } \\
\text { phase of budget proposals }\end{array}$ \\
\hline Intentional biases in the negotiations & $\begin{array}{l}\text { Reflections on the interaction, strategy, and } \\
\text { actions of municipal managers during the annual } \\
\text { budgeting process }\end{array}$ \\
\hline Blame avoidance in the final decision-making & $\begin{array}{l}\text { The reactions of the hospital district board to the } \\
\text { budget proposal, and the budget and health care } \\
\text { professionals' response to the board's reaction }\end{array}$ \\
\hline
\end{tabular}

\section{Empirical analysis}

A realistic, target-oriented, but feasible budget: a balancing act on the edge of the precipice

The CFOs generally thought that there is no special economic and budgetary steering separated from service structures and production processes: "The financing and the operation are quite organically connected here, because the cash flow is created on the basis of the amount and quality of the productionwith some exceptions - unlike in the municipalities where the tax revenues and state subsidies come as lump sums." Budget figures should be based on the planned changes of operations, and budget figures and accounts match only if the plans are realized. The budget framework, and the final budget as well, "must be tighter than slack, but nevertheless still realistic. Target-orientation is good if the plans and targets included in the budget are synchronous with each other."

Here, "realism" means minimizing the discrepancy between budget targets, decisions, and execution. Careful and accurate planning of improvements to operations - "the details" - is the most central part of a realistic budget process. The biggest challenge in budgeting is "the execution of budgetary targets via effective operational programs. The targets deviate from the present situation and they are based on improving the operations." The operational processes of health care are usually long, strongly institutionalized, complex, and sensitive. The change projects of such processes contain the risk of unintentional cognitive biasing.

Changes in operations require thorough preparation, which includes securing the professionals' commitment. Otherwise, for example, "new ideas and operation models are superimposed over old practices, and the old practices are relinquished unwillingly or in an ineffective manner." Conversely, "when the leaders and superiors are committed to the management of change, when they operate actively and exemplarily, the changes almost always succeed." The commitment of leaders and superiors is not enough, however, because health services are produced at the "moment of truth," where the client interacts face to 
face with the physician or nurse (Pettersen 1995). The understanding of this moment and the "small daily situations and tasks are the most important and decisive in the control of the finances."

It is not easy to ensure commitment to economic targets, because the idea of causality between medical operations and the economy of such operations is not often clear to the health care professionals. One of the main tasks of CFOs is to exemplify the operational-economy causality in theory, e.g., in seminars and programs, but also in practice. CFOs especially appreciate the younger, management-oriented generation, but recognize the variety and differences among them in managerial activity: "even though doctors are eager developers, the enthusiasm for saving has not been so great." Sub-optimization also takes place within hospital districts: "there is much sub-optimization in this system. Each specialty looks after its own and then turns its back." These incidents indicate that some amount of budgetary slack has been traditionally accepted in most hospital districts. CFOs avoid slack by forming networks with leaders of medical units. Networking and interdisciplinary training and consulting have not spread to all hospital districts, however.

Often CFOs consider it difficult or even impossible to make realistic budgets. In hospital districts where binding contracts over the acquisition of services are used, it is typical that the new service contracts are smaller than the previous ones. In this case, most CFOs choose a deficit budget to try to avoid upward bias in expenses and revenues. If this is not possible, the risk of ritualizing the budgeting process is evident: "In October I saw that an unrealistic budget was being prepared for the next year. Still, it did not worry them... The budget is made, the figures are arrived at in accordance with the acquisition agreements, but the listings required to meet the budget are nowhere to be found..." Wide participation alone does not guarantee commitment and good results. Ritualism reduces the contribution of budgeting to the efficiency of operational units.

Furthermore, there is evidence of a budgetary slack strategy referred to as "minimizing the blame." This occurs when the acquisition costs of particularly expensive treatments from university hospitals are intentionally and continuously underestimated, because their overruns are "less blameworthy" as they "sort of have a life of their own." By doing so, it is possible to allocate more resources to personnel costs, which are under tight control (budgetary slack). The amount of treatments and the degree of their complexity are the most general biasing objects, because they affect costing and pricing, and they are reflected in the execution of the budget.

\section{The municipal managers: counterbiasing via the slogan of "saving"}

Primary health care and specialized medical care hospitals are separate organizations, and they compete for the same municipal finances. CFOs are aware that in the municipalities and the municipal health centers, "funding has long been a strict master." Furthermore, they are unanimous in their belief that in order "to save," municipal managers like to give hospital districts tight financial frameworks without any operational or functional steering. For example, the municipal managers only look at the "cold numbers, how many millions or what percentage, nothing else." One CFO recalled an exceptional negotiation, where "municipal manager X made some operational proposals, the other at once said that let's not intervene in the operations; it's better still to control using money."

The tight framing is intelligible as a budgetary message, because health care is only one of many important municipal services. However, the patient flow between primary care and hospitals is substantial, generating a great degree of interdependence between the actors. The lack of operational coordination and steering introduces silo effects and reduces the concern for the patients, because "nobody is responsible for the patient's care chain as a whole." CFOs recognized the existence of the care chain in theory, but they were 
rather skeptical of the functioning of this perspective in budgeting practice: "In the negotiations, even professionals are committed to their own box; the whole care chain is not observed. In recent years at least, when economic pressure has continued, the amount of the sub-optimization has increased."

In some smaller hospital districts, among the so-called multifunctionals (see Appendix 1), the care chain has been administratively unified by moving the responsibility for most of the primary health care from the municipality to the hospital district level. The CFOs had some evidence of the improvement of care integration and service structure rationing in those organizations. Budgetary problems still remained, e.g., the creation of significant deficits (Appendix 2) and growing problems with cost control, "because the decisions are based on the specific needs of each separate municipality." Although municipal managers may agree on the principle of saving, the size and location of the municipality and its existing service structure introduce different targets concerning service structures and complicate decision-making in the hospital district.

In the negotiations between the municipalities and the hospital districts, there are often situations in which the municipalities consider the proposals of the hospital management team too loose (exhibiting budget slack) while the hospital management team consider the municipality's proposals too strict (exhibiting upward bias). This happens, because "in the planning process, the need for services is always underestimated. When municipalities have indicated that during the next year, the growing population will not need any more services, we have believed them."

The remarkable exceptions to the control of "cold money" are major hospital renovations and other new investments, which have been topical in Finland because a considerable number of the central hospitals date from the 1970s and 1980s. Hospital managers and their consultants have argued that the investment plans are credible, promising improved efficiency and quality of care in the hospital. Behind the ambitious efficiency promises, there are calculations that include both the risks of unintentional cognitive biases and intentional upward biases. Calculations are made keeping in mind that "the actual and important purpose of calculations is to justify decision-making for the investment." Investments are assessed mainly from the viewpoint of the economic and social development (e.g. increase in employment) of the region, with the promised growth in efficiency taking care of the financing.

The concept of budgetary "realism" is ambiguous in health care systems where two organizations with different working cultures fight for the same budget allocations. In the municipalities, the budgeting emphasis lies in restricting infinite yearly service needs, while health care professionals in the hospital districts aim primarily at producing more health because of its positive long-term cost-benefit ratio. The operational model of municipal managers resembles the "frame budgeting" idea of New Public Management and also the idea of budgeting the "totals" (White, 2013) at the upper levels of the health care administration. In both of cases, the professionals of the field are left with the responsibility for the "details" of the operation.

\section{The boards of the hospital districts: balancing between professionals, patients, and voters}

The budget process is communicative and iterative all year round, and it includes several rounds of participation by the hospital district boards. The flow of information is immense, and routine budgets that do not involve any changes to highly valued local services are usually accepted unanimously and with little debate. More difficult are decisions which bring advantages to one party and disadvantages to another, as the disadvantages appear quickly and the advantages slowly. Tricky situations arise where economic restrictions force closures, other changes in the availability of services, or the intensification of work of the 
hospital staff. The budget proposals, which are prepared under the firm control of the management team of the hospital districts and municipal managers, are more or less biased.

The members of the boards come "from the top level of political decision-makers in the municipalities." The governance practices of boards vary greatly, from the relatively independent authority that decides "that our board has kept a very tight line-it is the board that decides" to a close dependence on what the municipal leaders have decided and declared, "our board does not decide against the will of the bigger municipalities ... even if it is difficult for us or sometimes ... impossible indeed to execute."

There is a temptation to employ delay strategies (White, 2013; Hood, 2007) by postponing tricky decisions. Therefore, tensions accumulate at the end of the year. The decisions made at the end of the year are the worst if the implementation programs of the preliminarily accepted operational plans are rejected or delayed: "It is a great challenge to create and retain the motivation and commitment of the professionals when the plug is pulled at the final stage of the process." The same frustration applies when "a million or two of the municipality's payments are taken away in the last meeting without talking about whether any changes in operations can be made as a consequence."

In the opinions of the CFOs-and the municipal managers as well-there are still many opportunities to take up slack in hospital districts, e.g., via developing the division of labor. In small hospital districts, "in many specialties, the problem is a lack of patients; this may result in referrals to the specialist units even when patients do not necessarily need such specialist care." Developing the division of labor between the hospital districts in schemes-such as shared specialists in small specialties-would solve the problem, but "usually the decision-makers' counterreaction is strong resistance, which is based only on politics or feeling." Furthermore, "our problem has been particularly discordant decision-making. Even though we have had the desire, interest, and commitment ... the decision-makers do not want to make the necessary decisions."

Situations where political decision-making seems to act as an obstacle are remembered for a long time. Furthermore, such situations damage the commitment of health care professionals who participated in the preparation of the budget. Budgeting professionals, however, understand the sensitivity in decisionmaking, because in most cases, discordances between different municipalities are the fundamental reasons for problems in decision-making. Negative news always results in recriminations and resistance, undermining the legitimacy of the decision-makers and the organization, since they usually affect jobs and livelihoods in the area.

In Finland, the strategy of "taking responsibility for efficiency" (Brunsson 1989) has often been used during fiscal stress, especially in connection with investment decisions. Tricky decisions and control using a tight financial framework may work well when there is a relationship of confidence and mutual understanding between all actors within the budget community. In one hospital district, "an established practice has been, for about five years, to make operational plans in the hospital district, while the budget framework comes from municipal negotiators and politicians. Both of these are included in budgets and executed in most cases as such. The use of material infrastructure and medical technology are at the top level, and the next goal is to improve the patients' flow." Such harmony is unusual in most hospital districts. The boards of hospital districts appear to most CFOs as court-like institutions that give legitimation to organizations via accepting or rejecting the decisions without paying much attention to organizational efficiency and effectiveness. 


\section{Discussion}

Budgeting includes year-round iterative activities, from target-setting to final decision-making. Budgeting participants have typical attitudes and experience pressures that depend on the structure of the health care system and their role and position in the budgeting process. The budgeting participants have conflicting aims and are themselves bounded rational individuals with cognitive constraints. For these reasons, budgets always include some bias, which is understood in this paper as a situation where the budget estimates deviate from the best possible budget estimate in some direction (Wildavsky, 1975, 1988; Lukka, 1988; Kahneman, 2002; White, 2013).

There are many reasons why the health care system context is subject to budgetary biasing and gaming (Ouchi, 1979; Kissic, 1994; Pettersen, 1995; White, 2013). In Finland, the public health care system contains a few structural and institutional characteristics that may facilitate a budgetary bias, or at least the risk for budgetary bias. The existing institutional framework is divided into separate organizations and there is no one party with overall responsibility for either the individual single patient's care or the overall service system. Moreover, controversy over the municipality-specific or the wider regional perspective hampers decision-making. Different orientations on the emphases of budgeting and effective budget control between hospital districts and municipalities have introduced continued conflict, which however varies in its intensity and focus (Karila et al., 2017). In practice, the result depends on the importance of varying situational factors, like the amount of confidence and trust between organizations and their key budgeting participants. In the framing phase of the budget, for instance, a situation like "we know what they say to us, and they know that we say something more" may be either innocent gaming or severe conflict.

Table 3 introduces as a result of the article the typology of biases, biasing actors, the actors' intentions, the forms and implications of bias, and the prevention strategies. It is evident that all groups are open at least to cognitive biases and blame avoidance.

Table 3. Types of bias and their manifestations in hospital budgeting.

\begin{tabular}{|c|c|c|c|c|}
\hline Types of bias & $\begin{array}{l}\text { Main biasing } \\
\text { actors }\end{array}$ & $\begin{array}{l}\text { Drivers / } \\
\text { intentions of } \\
\text { bias }\end{array}$ & $\begin{array}{l}\text { Forms and } \\
\text { implications of bias }\end{array}$ & $\begin{array}{l}\text { Prevention } \\
\text { strategies }\end{array}$ \\
\hline $\begin{array}{l}\text { Unintentional cognitive } \\
\text { biases because of } \\
\text { bounded rationality, } \\
\text { cognitive constrains, } \\
\text { defective information, } \\
\text { and information } \\
\text { asymmetry between } \\
\text { budgeting participants. }\end{array}$ & $\begin{array}{l}\text { Leaders and key } \\
\text { budgeting } \\
\text { participants of } \\
\text { clinics and other } \\
\text { operational units, } \\
\text { which have the } \\
\text { stance of } \\
\text { advocates. }\end{array}$ & $\begin{array}{l}\text { Loss aversion in } \\
\text { situations in } \\
\text { which the } \\
\text { information is } \\
\text { defective and the } \\
\text { future is } \\
\text { uncertain. }\end{array}$ & $\begin{array}{l}\text { Estimation errors in the } \\
\text { preparatory phase of } \\
\text { budgeting. } \\
\text { Personal goals and } \\
\text { thinking only "the best } \\
\text { for patients". }\end{array}$ & $\begin{array}{l}\text { Increase the } \\
\text { consciousness of } \\
\text { cognitive biases and their } \\
\text { effects in the budgeting } \\
\text { process. } \\
\text { Networking with } \\
\text { counterparts to learn to } \\
\text { understand and access } \\
\text { their needs and } \\
\text { arguments, too. }\end{array}$ \\
\hline $\begin{array}{l}\text { Budgetary } \\
\text { slack }\end{array}$ & $\begin{array}{l}\text { Typical for the } \\
\text { actors which have } \\
\text { the stance of } \\
\text { advocate. }\end{array}$ & $\begin{array}{l}\text { Resource } \\
\text { intention: to } \\
\text { secure the } \\
\text { resources for } \\
\text { their own unit. } \\
\text { Performance } \\
\text { evaluation } \\
\text { intention: to }\end{array}$ & $\begin{array}{l}\text { Overestimation of the } \\
\text { costs and/or } \\
\text { underestimation of } \\
\text { performance capacity. } \\
\text { Sub-optimization as a } \\
\text { means for resource } \\
\text { intention and } \\
\text { slack formulation. }\end{array}$ & $\begin{array}{l}\text { Networking with their } \\
\text { "own" health care } \\
\text { professionals and } \\
\text { counterparts. } \\
\text { Avoiding "empty } \\
\text { promises" and other } \\
\text { ritualistic budgeting } \\
\text { practices, a deficit }\end{array}$ \\
\hline
\end{tabular}




\begin{tabular}{|c|c|c|c|c|c|}
\hline \multirow{3}{*}{$\begin{array}{l}\text { Intentional } \\
\text { biasing }\end{array}$} & & & $\begin{array}{l}\text { make the budget } \\
\text { easier to meet. }\end{array}$ & & \multirow{3}{*}{$\begin{array}{l}\text { budget in certain } \\
\text { situations. } \\
\text { Following fiscal rules and } \\
\text { principles of budgetary } \\
\text { governance. } \\
\text { To learn to understand } \\
\text { and access the needs and } \\
\text { arguments of all } \\
\text { counterparts involved in } \\
\text { the budgeting process. } \\
\text { Counterbiasing may also } \\
\text { work as a strategy for } \\
\text { avoiding biases in certain } \\
\text { situations. }\end{array}$} \\
\hline & $\begin{array}{l}\text { Upward } \\
\text { bias }\end{array}$ & $\begin{array}{l}\text { Typical for the } \\
\text { actors which have } \\
\text { the stance of } \\
\text { guardian, the } \\
\text { management team, } \\
\text { and budget experts. }\end{array}$ & $\begin{array}{l}\text { Motivation } \\
\text { intention. }\end{array}$ & $\begin{array}{l}\text { Opportunity for } \\
\text { moderate slack for } \\
\text { health care } \\
\text { professionals. } \\
\text { Upward bias (promises } \\
\text { too brave), e.g., in the } \\
\text { case of investments. }\end{array}$ & \\
\hline & $\begin{array}{l}\text { Counter- } \\
\text { biasing }\end{array}$ & $\begin{array}{l}\text { Typical for the } \\
\text { negotiators in the } \\
\text { principal - agent } \\
\text { chains, with } \\
\text { information } \\
\text { asymmetry. }\end{array}$ & $\begin{array}{l}\text { Eliminate the } \\
\text { probable slack of } \\
\text { other actors, for } \\
\text { sure. }\end{array}$ & $\begin{array}{l}\text { Gaming in the } \\
\text { negotiations, e.g. } \\
\text { avoiding responsibility } \\
\text { for the operative } \\
\text { details. }\end{array}$ & \\
\hline \multicolumn{2}{|c|}{ Blame avoidance } & $\begin{array}{l}\text { Typically, blame } \\
\text { avoidance arises at } \\
\text { the level of political } \\
\text { decision-making, } \\
\text { even it appears at } \\
\text { all the levels of the } \\
\text { organization. }\end{array}$ & $\begin{array}{l}\text { To avoid the risk } \\
\text { of blame. }\end{array}$ & $\begin{array}{l}\text { Intentional under- } \\
\text { budgeting from year to } \\
\text { year, coming partly } \\
\text { from timing and the } \\
\text { demand for unanimous } \\
\text { decision-making. }\end{array}$ & $\begin{array}{l}\text { Informing inhabitants } \\
\text { and appealing to the } \\
\text { voters' support, to } \\
\text { promote agreeable } \\
\text { projects and to reject } \\
\text { undesirable projects. }\end{array}$ \\
\hline
\end{tabular}

Leaders of health care professionals and their subordinates work in the best interests of their patients while at the same time securing their own legitimacy and professional advantages (Freidson, 1988). They are advocates in their budgeting style, and their motivation stems from the "resource intention" and "performance evaluation intention" (Lukka, 1988), which typically produce an overestimation of costs and estimation errors. Furthermore, the efficiency of operative action and the outcome of budgeting are decisively realized at the performative level in the controlled units despite the budgeting (Vakkuri, 2010), because the "ward managers' phone and the physicians' pencil are the most important cost drivers in the hospital," as one of the medical managers put it. Clinical norms follow the logic of appropriateness: medical professionals are loyal to their patients, and everything necessary is done to follow the clinical norms and rules and traditions (March \& Olsen, 2011; Pettersen, 1995).

The amount of intentional biasing depends on the role of the management team and other budgeting experts in the central administration and other units. Hospital CFOs seemed to motivate subordinates to prepare as honest a budget as possible. In doing so, they aim to set the budget at an optimistic level in order to gain the best motivational effect, which may mean either an intentional upward bias or the creation of slack - or, at least, providing a controlled level with an opportunity for the creation of slack (Lukka, 1988). At the same time, CFOs fight against ritualism and promote the value of budgeting by training the managers and other key members of medical staff, thus aiming to ensure that budget allocations are always based on operational, feasible plans of execution. The need for this work never ends, because new management and budgeting instruments are easily introduced and adapted to the strongly institutionalized existing practices (Hyvönen and Järvinen, 2006), and good management practices are crucial also in health care (Bloom et al., 2010).

Although municipal managers and municipal health center managers represent the owners of hospital districts, they often feel like underdogs in the budgeting process. The relations between the two guardian groups resemble principal-agent relations (Tynkkynen et al., 2013), where the principals feel they do not know enough about the details. For this reason, municipal managers suspect that there is always slack in 
hospital districts budgets. This brings us to the counterbiasing at the level of totals, while operational problems and the allocation of cuts remain the producers' task. This may continue year after year.

Both the guardians and boards of hospital districts represent their actions and decisions mainly in strategies, plans, and clear and measurable decisions (March and Olsen, 2013). The members of boards in particular aim to make sure that the decisions are acceptable enough to voters and patients. They avoid the risk of blame by timing and striving for unanimous decisions, underlining that every participant has a similar responsibility for the details and risks of the decision (Brunsson, 1989; Hood, 2007).

In Finland, all the actor groups in the budgeting process understand now - at least in principle-the importance of mutual confidence and commitment to the common aims, even without full consensus. Reasons for this may be considerable long economic stagnation, together with new legislation that is more explicit in demanding a rapid reduction in hospital district and municipal deficits (Kuntalaki, 2015). Decisions about several problematic "bottlenecks" in the hospital districts have been made in budgets and separately, but there is no evidence-based information yet about how much they utilize the efficiency of action.

\section{Conclusions}

The purpose of the study was to introduce the concepts and forms of budgetary bias to the study of the budgeting processes in public hospitals, where this kind of behavioral analysis is still undeveloped.

Budget participants have conflicting interests, the budget is a time-bound compromise, and gaming and biases are inevitable aspects of this process. Many features of health care organizations make them susceptible to budgetary bias. Recognizing these features and typical forms of bias help to control the budgeting process and to possibly introduce a more realistic and feasible budget.

The article provides a typology of biases in the budgeting process. The three concepts of bias were examined simultaneously, because they all affect budgeting and the final budget. The concepts proved to be useful and highlighted central empirical assumptions and preliminary results about biasing dynamics. We also observed that the concepts were useful in understanding budgetary bias dynamics in the context of the Finnish hospital system. However, the same kind of tensions that produce the budgetary bias are found also in other Beveridge type health systems, e.g., between professions and management and between providers and producers.

We have interviewed only the CFOs of hospital districts, and they comprise only one group in the budgeting process. The data reflect above all what the process looks like from the point of view of CFOs. However, when the role of the empirical analysis is mainly to illustrate concepts and test their suitability in the context of public hospitals, the data are applicable for the purpose.

Our results are preliminary and it would be important to analyze their validity and usefulness with data sources reflecting the viewpoints of the other important budget actors. In our experience, however, the management of the municipalities and the directors of the medical services in hospitals also identify the same problems in budgeting, although the idea of what constitutes a realistic budget varies.

Our article provides novel perspectives on the uses of budgetary biasing concepts in the health care sector, where budgeting problems are extremely difficult to solve and are still narrowly understood. Our results help to focus attention on the participants and critical phases of the budgeting process in health care systems. Understanding the dynamics of biasing may help in examining why biasing behavior so often appears in the budgeting process, and it may contribute to understanding whether the bias may be 
considered functional or dysfunctional. More case studies and comparative studies are needed to explore the varying forms and effects of budgetary bias in different types of health care systems.

\section{References}

Alestalo, M. and Åkerman M. (2010), Asiantuntijahaastattelun analyysi: faktojen jäljillä. In J. Ruusuvuori et al. (eds), Haastattelun analyysi (pp. 372-392). Tampere. Vastapaino.

Anessi-Pessina, E. and Sicilia, M. (2015), Biased Budgeting in the Public Sector: Evidence from Italian Local Governments. Local Government Studies, Vol. 41, No. 6, pp. 819-840.

Anessi-Pessina, E. et al. (2016). Public sector budgeting: A European review of accounting and public management journals. Accounting, Auditing \& Accountability Journal, Vol. 29, No. 3, pp. 491-519.

Berwick Donald M. et al. (2008), The Triple Aim: Care, Health, And Cost. HEALTH AFFAIRS, Vo I. 2 7, N o 3. https://www.healthaffairs.org/doi/full/10.1377/hlthaff.27.3.759 (Accessed March 20, 2019).

Bloom et al. (2010), Why good practices really matter in healthcare. VOX, CEPR's Policy Portal.

Brunsson, N. (1989), The Organization of Hypocrisy. Chichester: John Wiley \& Sons.

Budding, T. Grossi, G. (2014), Public sector budgeting. In Budding T. et al. (eds), Public sector accounting (pp. 122-144). https://books.google.fi/books?id=VEVHBAAAQBAJ\&dq=decrementalism\&hl=fi\&lr (Accessed September 15, 2017).

Caiden, N. (2010). Challenges Confronting Contemporary Public Budgeting: Retrospectives/Prospectives from Allen Schick. Public Administration Review, Vol. 70, No. 2, pp. 203-210.

Collins, F. et al. (1987), The Budgeting Games People Play. The Accounting Review, Vol. 62, No. 1, pp. $29-49$.

Davila, T. and Wouters, M. (2005), Managing budget emphasis through the explicit design of conditional budgetary slack. Accounting, Organizations and Society, Vol. 30, No. 7-8, pp. 587-608.

Dunk, A.S. and Nouri, F. (1998), Antecedents of Budgetary Slack: A Literature Review and Synthesis. Journal of Accounting Literature, Vol. 17, pp. 72-96.

Eijkenaar, F. (2013), Key issues in the design of pay for performance programs. European Journal of Health Economics, Vol. 14, No. 1, pp. 117-131.

Freidson, E. (1988), Profession of Medicine. Chicago \& London: University of Chicago Press.

Griffin, S. et al. (2011), Dangerous omissions: the consequences of ignoring decision uncertainty. Health Economics, Vol. 20, No. 2, pp. 212-224.

Hofstede, G. H. (1968), The Game of Budget Control. London: Tavistock.

Hood, C. (2007), What happens when transparency meets blame avoidance? Public Management Review, Vol. 2, pp. 191-210.

Huang, C-L. and Chen, M-L. (2010), Playing devious games, budget-emphasis in performance evaluation, and attitudes towards the budgetary process. Management Decision, Vol. 48, No. 6, pp. 940-952.

Hyvönen, T. and Järvinen, J. (2006), Contract-Based Budgeting in Health Care: A Study of the Institutional Process of Accounting Change. European Accounting Review, Vol. 15, No. 1, pp. 3-36. 
Johanson, J. E. and Vakkuri, J. (2018), Governing Hybrid Organizations. Exploring Diversity of Institutional Life. Routledge.

Kahneman, D. (2002), Maps of bounded rationality: A Perspective on intuitive judgement and choice. http://helios.uta.fi/docview/233028000?accountid=14242

Karila, A. et al. (2015), Eriytettyjen talousyksiköiden ohjauksen ongelma - Perussopimukset sairaanhoitopiirien talouden hallinnassa. Kunnallistieteellinen Aikakauskirja. Vol. 42, No. 2. pp. 144-165.

Karila, A. et al. (2017), Budjettiharha julkisessa toimeksiantotaloudessa - esimerkkinä sairaanhoitopiirit. Hallinnon tutkimus, Vol. 36, No. 1, pp. 36-52.

Kissick, W. (1994), Medicine's Dilemmas: Infinite Needs versus Finite Resources. New Haven, CN: Yale University Press.

Kuntalaki 410/2015. https://www.finlex.fi/fi/laki/alkup/2015/20150410

Kurunmäki, L. (2004), A hybrid profession: The acquisition of management accounting expertise by medical professionals. Accounting, Organizations and Society, Vol.29, No. 3-4, pp. 327-347.

Lukka, K. (1988), Budgetary biasing in organizations: Theoretical framework and empirical evidence. Accounting, Organizations and Society, Vol. 13, pp. 281-301.

March, J. G. (1978), Bounded Rationality, Ambiguity and the Engineering of Choice. Bell Journal of Economics, Vol. 9, No. 2, pp. 587-608.

March, J. G. and Olsen, J. P. (2013), The Logic of Appropriateness. In Goodin, R. E. (ed.) The Oxford Handbook of Political Science.

http://www.oxfordhandbooks.com/view/10.1093/oxfordhb/9780199604456.001.0001/oxfordhb9780199604456-e-024 (Accessed April 5, 2017).

OECD (2016), Health at a glance: Europe 2016. OECD/European Union.

Otley, D.T. (1985), The Accuracy of Budgetary Estimates: Some Statistical Evidence. Journal of Business Finance \& Accounting, Vol. 3, pp. 415-428.

Ouchi, W. A. (1979), Conceptual Framework for the Design of Organizational Control Mechanisms. Management Science, Vol. 25, No. 9, pp. 833-848.

Pettersen, I. J. (1995), Budgetary Control of Hospitals - Ritual rhetorics and rationalized myths? Financial Accountability \& Management, Vol. 11, No. 3, pp. 207-221.

Propper, C. and Leckie, G. (2011), Increasing competition between providers in health care markets. In Glied, S. \& Smith, P. G. (eds), The Oxford Handbook of Health Economics. Oxford: Oxford University Press.

Rogers, R. (2012), Leadership communication styles: A descriptive analysis of health care professionals. Journal of Healthcare Leadership. Vol. 4, pp. 47-57. DOI:10.2147/JHL.S30795.

Rozin, P. and Royzman, E. B. (2001), Negativity Bias, Negativity Dominance and Contagion, Personality and Social Psychology Review, Vol. 5, No. 4, pp. 296-320.

Saltman, R. B. et al. (eds.) (2011), Governing Public Hospitals. World Health Organization. Observatory Studies Series No.25.

Schick, A. (1988), An Inquiry into the Possibility of a Budgetary Theory. In Rubin, I. (ed), New Directions in Budget Theory. Albany: State University of New York Press. 
Schick, A. (1986), Macro-Budgetary Adaptations to Fiscal Stress in Industrial Democracies. Public Administration Review, Vol. 2, pp. 124-134.

Schick, A. (2009), The Role of Fiscal Rules in Budgeting, in OECD (Ed.) Evolutions in Budgetary Practice. Paris: OECD Publishing, pp. 319-341.

Scott, R. W. et al. (2000), Institutional Change and Health Care Organizations: From Professional Dominance to Managed Care. Chicago: University of Chicago Press.

Seppälä, T. and Pekurinen, M. (eds.) (2014), Sosiaali- ja terveydenhuollon keskeiset rahavirrat. Raportti 22, THL.

Silverman, D. (2006). Interpreting Qualitative Data: Methods for Analyzing Talk, Text and Interaction. Sage.

Simon, H. A. (1991), Bounded Rationality and Organizational Learning. Organization Science Vol X, No. 1, pp. 125-134.

Smith, P. C. et al. (1997), Principal-agent problems in health care systems: An international perspective. Health Policy, Vol. 41, No. 1, pp. 37-60.

Swain, J. W. and Hartley, J. (2001), Incrementalism: Old but good? In Bartle John R. (ed), Evolving Theories of Public Budgeting. Oxford: Elsevier Science Ltd.

Thaler, R. H. (2015), Misbehaving: The Making of Behavioral Economics. New York: W.W. Norton \& Company.

THL (2016), www.thl.fi/fi/web/sote-uudistus/palvelujen-jarjestaminen/palvelujen-jarjestamisennykytilanne-suomessa (Accessed September 15, 2017).

THL (2018), https://www.thl.fi/fi/web/thlfi-en/statistics/information-on-statistics/qualitydescriptions/hospital-benchmarking (Accessed February 13, 2018).

Tynkkynen, L-K. et al. (2013), Purchaser-provider splits in health care: The case of Finland. Health Policy, Vol. 111. No. 3, pp. 221-225 (Accessed February 2, 2018).

https://doi.org/10.1016/j.healthpol.2013.05.012

Vakkuri, J. (2010), Struggling with ambiguity: Public managers as users of NPM_oriented management instruments. Public Administration, Vol. 88. No. 4, pp. 999-1024. DOI: 10.1111/j.1467-9299.2010.01856.x

Van der Stede, W. (2000), The relationship between two consequences of budgetary controls: Budgetary slack creation and managerial short-term orientation. Accounting, Organizations and Society, Vol. 25, No. 6, pp. 609-622.

White, J. (2013), Budget-makers and health care systems. Health Policy, Vol. 112, No. 3, pp. 163-171. http://dx.doi.org/10.1016/j.healthpol.2013.07.024

Wildavsky, A. (1975), Budgeting, A Comparative Theory of Budgetary Processes. Boston: Little, Brown and Company.

Wildavsky, A. (1988), The New Politics of the Budgetary Process. Berkley: HarperCollins. https://www.stat.fi/til/vtp/2017/vtp 2017 2018-03-16 tau 001 fi.html 


\begin{tabular}{|c|c|c|c|c|c|c|c|c|c|}
\hline $\begin{array}{l}\text { Appendix 1. INDICATC } \\
\text { Sources: Statistics Fin }\end{array}$ & $\begin{array}{l}\text { RS OF HOSPI } \\
\text { and, The Ass }\end{array}$ & $\begin{array}{l}\text { TAL DISTRIC } \\
\text { ociation of }\end{array}$ & $\begin{array}{l}\text { TS AND } \\
\text { Finnish L }\end{array}$ & $\begin{array}{l}\text { SPECIAL RE } \\
\text { ocal and R }\end{array}$ & $\begin{array}{l}\text { ESPONSIBILITY } \\
\text { Regional Autho }\end{array}$ & $\begin{array}{l}\text { Y AREAS OF } \\
\text { orities and }\end{array}$ & $\begin{array}{l}\text { F UNIVER } \\
\text { Authors. }\end{array}$ & RSITY HOSPIT & ALS \\
\hline $\begin{array}{l}\text { Area / name of } \\
\text { hospital district }\end{array}$ & $\begin{array}{l}\text { Catchment } \\
\text { population } \\
31.12 .2015\end{array}$ & $\begin{array}{l}\text { Change in } \\
\text { catchment } \\
\text { population } \\
2000-2015,\end{array}$ & $\begin{array}{l}\text { Number } \\
\text { of } \\
\text { munici- } \\
\text { palities }\end{array}$ & $\begin{array}{r}\text { Operation } \\
2016 \text { a } \\
\text { specialize } \\
\end{array}$ & $\begin{array}{l}\text { hal expenditure } \\
\text { and share of } \\
\text { ed medical care } \\
\text { (SMC) }\end{array}$ & $\begin{array}{r}\text { Deviatior } \\
\text { budget } \\
\text { expen }\end{array}$ & $\begin{array}{l}\text { ns betweel } \\
\text { ts and acc } \\
\text { diture } 201\end{array}$ & $\begin{array}{l}\text { en original } \\
\text { counts in } \\
10-2014\end{array}$ & $\begin{array}{c}\text { Surplus / deficit } \\
\text { in balance sheet } \\
\begin{array}{c}31.12 .2014, \% \text { of } \\
\text { operational }\end{array}\end{array}$ \\
\hline & & & 2017 & \begin{tabular}{|c|} 
Total, \\
millions
\end{tabular} & $\begin{array}{r}\text { Share of SMC, \% } \\
\text { Multifunctionals }\end{array}$ & $\begin{array}{c}\text { Average per } \\
\text { year, } \%\end{array}$ & \begin{tabular}{|l|} 
Standard \\
deviation
\end{tabular} & $\begin{array}{c}\text { Suplementary } \\
\text { budget }\end{array}$ & revenue \\
\hline Helsinki and Uusimaa & 1616321 & 16.3 & 24 & 1911.5 & & 102.7 & 1.3 & 0.9 & 0.0 \\
\hline South Karelia & 131155 & -3.8 & 9 & 498.1 & 36.1 & 101.5 & 1.4 & 0.8 & -5.7 \\
\hline Kymenlaakso & 171778 & -4.5 & 6 & 200.1 & 89.5 & 102.0 & 4.4 & -0.0 & -10.9 \\
\hline HYKS sra & 1919254 & 12.5 & 39 & 2609.7 & & & & & \\
\hline North Savo & 248129 & -2.1 & 18 & 421.6 & & 102.4 & 2.1 & 2.6 & -2.6 \\
\hline South Savo & 103278 & -8.2 & 9 & 168.3 & & 105.2 & 1.9 & 1.3 & -3.4 \\
\hline East Savo & 43453 & -12.2 & 4 & 153.6 & 49.1 & 102.5 & 1.8 & 1.9 & 0.0 \\
\hline Central Finland & 251904 & 6.0 & 21 & 349.4 & 90.8 & 104.3 & 1.0 & 0.0 & -4.4 \\
\hline North Karelia & 168329 & -4.5 & 14 & 245.5 & 92.4 & 103.2 & 2.8 & 2.5 & 0.2 \\
\hline KYS sra & 815093 & -1.8 & 66 & 1338.4 & & & & & \\
\hline North Ostrobothnia & 407160 & 10.2 & 29 & 589.2 & 96.3 & 103.6 & 1.5 & 3.3 & -3.2 \\
\hline Kainuu & 75324 & -12.1 & 8 & 372.9 & 36.5 & 100.6 & 2.9 & 1.0 & 0.2 \\
\hline Central Ostrobothnia & 78608 & 0.6 & 10 & 182.2 & 69.7 & 104.5 & 4.1 & 4.0 & 5.5 \\
\hline Lapland & 117789 & -4.4 & 15 & 183.1 & & 104.5 & 2.5 & 3.4 & 1.0 \\
\hline Länsi-Pohja & 63069 & -8.0 & 6 & 105.1 & & 106,064 & 106.1 & -0.0 & -2.8 \\
\hline OYS sra & 741950 & 2.3 & 68 & 1432.5 & & & & & \\
\hline Pirkanmaa & 526941 & 11.0 & 23 & 724.4 & 98.2 & 104.5 & 1.0 & 0.6 & 2.1 \\
\hline South Ostrobothnia & 197371 & -1.7 & 18 & 276.8 & & 101.7 & 1.9 & 0.7 & -2.1 \\
\hline Kanta-Häme & 174710 & 5.7 & 11 & 208.2 & & 102.0 & 1.7 & 0.0 & -12.3 \\
\hline Päijät-Häme & 212465 & 1.7 & 12 & 410.2 & 60.3 & 102.5 & 3.4 & 1.2 & -0.9 \\
\hline TAYS sra & 1111487 & 5.9 & 64 & 1619.6 & & & & & \\
\hline Southwest Finland & 477372 & 5.9 & 28 & 676.1 & & 104.3 & 1.6 & 0.3 & -1.4 \\
\hline Vaasa & 170212 & 5.6 & 17 & 223.2 & & 102.9 & 0.9 & 0.9 & 5.1 \\
\hline Satakunta & 222957 & -4.1 & 13 & 324.2 & 90.5 & 103.3 & 1.4 & -0.0 & -0.1 \\
\hline TYKS sra & 870541 & 3.1 & 58 & 1223.5 & & & & & \\
\hline $\begin{array}{l}\text { Finland (without } \\
\text { Åland Islands) }\end{array}$ & 5458325 & 5.9 & & 8223.7 & & 103.2 & & 1.3 & \\
\hline
\end{tabular}

https://www.kuntaliitto.fi/sites/default/files/media/file/Ervat_Sairaanhoitopiirit2017_0.pdf

https://www.kuntaliitto.fi/sites/default/files/media/file/Sairaaloiden-ja-sairaanhoitopiirien-tammi-joulukuu-2016_0.pdf http://www.stat.fi/til/vaerak/ 